\title{
Phenotypic Characterization and Strategies for Genetic Improvement of WAD Goats under Backyard Systems
}

\author{
S. O. Oseni ${ }^{*}$, B. A. Ajayi ${ }^{2}$ \\ ${ }^{1}$ Department of Animal Sciences, Obafemi Awolowo University, Ile-Ife, Nigeria \\ ${ }^{2}$ Department of Animal Science, Landmark University, Omu-Aran, Nigeria \\ Email: soseni@oauife.edu.ng
}

Received 20 July 2014; revised 5 September 2014; accepted 20 September 2014

Copyright (C) 2014 by authors and Scientific Research Publishing Inc.

This work is licensed under the Creative Commons Attribution International License (CC BY). http://creativecommons.org/licenses/by/4.0/

(c) (i) Open Access

\begin{abstract}
West African Dwarf (WAD) goats represent one of the predominant small ruminant breeds raised by resource-limited households in southern Nigeria as well as in the humid west and central Africa. This breed of goats is renowned for its adaptation to hot and humid environments, high fertility and prolificacy under backyard systems where they are raised almost with zero investment. On account of its contributions to household income and food security in southern Nigeria, there is the need for a detailed phenotypic and genetic characterization as well as the design of breeding strategies for its conservation through sustainable utilization. A critical challenge, however, is that there are no national breeding policies in most of the countries where WAD goats are raised. The objectives of this paper are: to review literature reports on trait-level information and estimates of genetic parameters for some economic characters of WAD goats; and to discuss a communal breeding scheme for its conservation through sustainable utilization. The presentation shows that WAD goats represent a highly diverse population, with particular reference to qualitative and performance-related traits, reflecting the role of traditional institutions in the maintenance of animal diversity in local populations. A genetic improvement programme involving dispersed open nucleus breeding scheme was discussed. The scheme involves backyard WAD goat units in villages as base population and dispersed communally managed schemes that maintain a population of bucks only, as nucleus units. Critical issues such as the definition of breeding goals by farmers, as well as communal project ownership, are emphasized. The ultimate goal of the breeding programme is to create opportunities for community-based management of WAD goat genetic resources for the benefit of backyard goat farmers in the region.
\end{abstract}

\section{Keywords}

WAD Goats, Characterization, Trait-Level Information, Genetic Improvement, Communal Breeding

${ }^{*}$ Corresponding author.

How to cite this paper: Oseni, S.O. and Ajayi, B.A. (2014) Phenotypic Characterization and Strategies for Genetic Improvement of WAD Goats under Backyard Systems. Open Journal of Animal Sciences, 4, 253-262.

http://dx.doi.org/10.4236/ojas.2014.45032 


\section{Scheme, Backyard Systems}

\section{Introduction}

West African Dwarf goats (also called Nigerian Dwarf, Kirdi or Kirdimi, Fouta Djallon, Cameroon Dwarf, African Pigmy [1] [2] are thought to have evolved from the Brevipes or short-legged goats. Epstein [3] described WAD goats as those whose average shoulder height does not exceed $50 \mathrm{~cm}$. Years of adaptation and natural selection under humid tropical conditions made this breed highly adapted to the humid forest zone [4]. These goats are present in all of humid Africa, from Southern Sudan to the west coast areas that are noticeably humid and warm [1], and characterized by dense vegetation ranging from swamp mangrove to rainforest and derived savannah. In these zones, ambient temperature and relative humidity are notably high all year round. Gall [1] and DAGRIS [2] listed some 16 countries in West and Central Africa where WAD goats are predominantly raised under backyard systems. The production system is mainly extensive, animals are allowed to roam and scavenge at will, with a preponderance of subsistence farming units. These countries are noted for high poverty levels [5], especially in the rural areas. Among the inhabitants, WAD goats are raised principally as a source of meat and other uses include socio-economic, ceremonial, cultural and traditional purposes, including divination.

WAD goats are highly prolific, can be bred all year round, with up to three parturitions in two years [6]. The goats are hardy, with the ability to thrive and survive under harsh environmental conditions of heat and humidity, ability to digest a broad range of diets and resistance to high-humidity pathogens and haemonchosis, tolerant of gastro-intestinal nematodes and trypanosomiasis [7]-[9] and the ability to thrive in tse-tse fly infested humid forests and guinea savannah zones [10] [11]. [12] noted that the mechanism of trypano-tolerance in goats, in general, differs from that of trypano-tolerant cattle. WAD goats have been described as trypano-"resilient", since, in the face of parasitic challenge, they maintained positive weight gain and recorded low mortality rates. This allows them to graze on land not available to other domestic livestock [8]. This author noted further that the ability of WAD goats to survive under adverse environmental conditions with low inputs makes this breed a low-risk choice, and this, according to [12], indicates their potential role for a more sustainable solution to the growing demand for animal protein in developing countries. Thus, [13] described WAD goats as an extremely valuable genetic resource on account of their entire package of adaptive traits.

Several investigators [1] [10] [13] [14] have reported cases of indiscriminate mating of WAD goats with Sahelian breeds of goats. In Nigeria, [10] noted specific cases of mating of WAD goats with the Red Sokoto breed, particularly in the transition zone between the rainforest and the derived savannah belt. In Burkina Faso, [14] reported that gene flow among Burkinabe goat populations (Djallonké or WAD goats, Mossi and Sahelian) was very high and this accounted for the low genetic differentiation among these breeds. All these practices contribute to an admixture of the gene pool which the WAD goat represents, indicating a general threat of introgression and dilution of its genetic base.

On account of its contributions to household income and food security in southern Nigeria, there is the need for a detailed genetic characterization as well as the design of breeding strategies for its conservation through sustainable utilization. A critical challenge however, is that there are no national breeding policies in most of the countries where WAD goats are raised, in spite of their contributions to the diversified livelihoods of resourcelimited farmers and to the rural economies. The objectives of this paper are: 1) To review literature reports on trait-level information (e.g. qualitative, morphological, functional and performance-related traits) as well as estimates of genetic parameters for these traits under on-station and on-farm conditions; 2) To discuss a communal breeding scheme for the conservation of WAD goats through sustainable utilization under backyard production systems in the humid west and central Africa.

\section{Trait-Level Information}

\subsection{Qualitative Traits}

WAD goats display wide variations in qualitative traits including coat colour pigmentation, wattles, beard and super-numerary teats among females. Coat colour pigmentations include predominantly black, brown white, pied and mixed colours [15] [16]. Figure 1 shows pictures of WAD goats from Ile-Ife and its environs in 

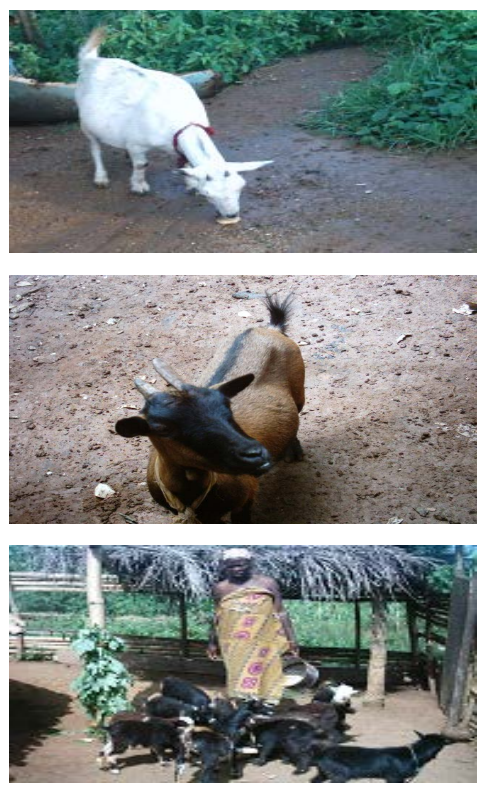
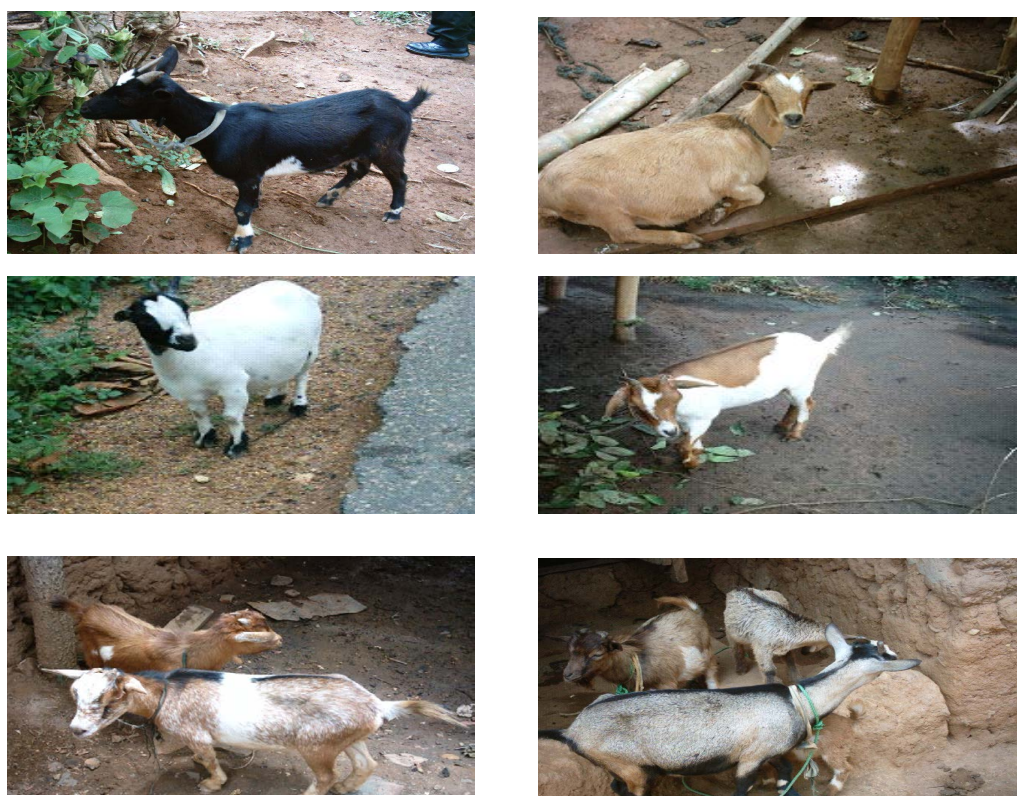

Figure 1. Diversity in coat colours of WAD goats under backyard systems in south-western Nigeria (Courtesy: S Oseni, WAD Goat field studies, southwest Nigeria, 2008).

south-western Nigeria, displaying all the afore-mentioned coat colours under backyard systems in the region. [15] noted that WAD goats had a preponderance of basic black coat colour (53.3\%) while basic brown and white goats were 39.9 and $6.8 \%$ respectively. Other qualitative traits displayed by WAD goats include wattles (bilateral, unilateral and WAD goats with no wattles), with frequency distributions of about $63 \%, 6.2 \%$ and $30.9 \%$, respectively, while the possession of beard is common among all breeding males and about $12 \%$ of breeding does.

Results of some fixed model analysis revealed that there were no significant differences among coat colour classes of dams in prolificacy, litter size at weaning and birth weight [17]. This author however, reported that WAD goats with basic white colours were significantly heavier at weaning and at yearling ages than basic brown and black goats. This observation was supported by [16] who reported that body weight of WAD goats decreased with increasing coat colour pigmentation. Other results of fixed model analysis showed that the possession of wattles did not exert any influence on the traits studied except yearling weight where bilaterally-wattled WAD goats were lighter in weight [17]. According to [18], visually obvious features such as coat colours and horns in primitive breeds of sheep are linked to properties of constitution that affect animal survival. Large scale studies are however, needed to establish the true roles of these qualitative traits on animal adaptation and performance and overall productivity of WAD goats under backyard systems.

\subsection{Reproductive Traits}

These include fertility, prolificacy, annual doe productivity and kid survival rate of WAD goats are shown in Table 1. Key literature sources for these information include the detailed review of goat breeds of Nigeria by [10] and scientific papers by [19]-[24], as well as the classical treatise "Goat Breeds of the World" [1].

According to [23], majority (75\%) of female WAD goats had their first kids at ages ranging between 14 and 20 months, which agreed with an earlier report [10] that the overall mean of age at first kidding was $18.5 \pm 1.2$ months. Doe prolificacy was $1.70 \pm 0.04$ [20] and was markedly affected by year of birth and parity [20] [25]. The relationship between litter size at birth and parity shows that prolificacy rose with parity up the $6^{\text {th }}$, and remained stable thereafter. With increasing parity, does are more mature and efficient in reproduction [25]. Overall means for kidding interval were $230 \pm 67$ to $283.15 \pm 6.79$ days [10] [21]. This trait was significantly affected by parity, year and season of birth and litter size at birth [20]. The relationship between kidding interval and doe parity showed that prolonged kidding intervals were associated with the first three parities, after which kidding intervals remained relatively constant at about $250 \mathrm{~d}$ [20]. Frequency distributions of kidding interval 
Table 1. Trait-level information from reproductive, growth and morphological characteristics of WAD goats from the literature.

\begin{tabular}{|c|c|c|c|}
\hline Trait & $\mathbf{n}$ & Mean $( \pm$ SE) & Source \\
\hline \multicolumn{4}{|l|}{ i. Reproductive and doe productivity index } \\
\hline Age at first kidding (months) & 371 & $18.5 \pm 1.2(\mathrm{SD})^{1}$ & {$[10]$} \\
\hline Litter size at birth & 220 & $1.70 \pm 0.04$ & [20] \\
\hline Kidding interval (days) & 209 & $283.15 \pm 6.79$ & {$[20]$} \\
\hline Kidding interval (days) & ----- & $230 \pm 67$ to $274 \pm 75$ & {$[21]$} \\
\hline Mortality (1 - 3 months, \%) & ----- & $22.6 \pm 15.9$ & {$[22]$} \\
\hline Pre-weaning mortality (\% born) & ----- & 17.3 to 28.8 & {$[24]$} \\
\hline Mortality to 1 year (\% of number weaned) & ----- & 0 to 4.9 & [24] \\
\hline Annual mortality rate (\%) & ----- & $29.1 \%$ to $49.5 \%$ (range) & {$[21]$} \\
\hline Reproductive index (Kg) & 245 & $6.5 \pm 3.7$ & {$[22]$} \\
\hline Reproductive index (Kg weaned/doe/year) & 33 & $6.5 \pm 5.5$ to $22.0 \pm 6.6$ & {$[24]$} \\
\hline Reproductive index (Kg weaned/doe/year) & ---- & 9.88 & {$[20]$} \\
\hline Annual doe productivity index (Kg yearlings/doe/year) & ---- & $5.3 \pm 3.9$ to $9.0 \pm 7.2$ & {$[21]$} \\
\hline \multicolumn{4}{|l|}{ Productivity index (Kg yearlings/doe/year) } \\
\hline Kid birth weight & 62 & $1.40 \pm 0.30$ & {$[24]$} \\
\hline Weaning weight & 49 & $6.40 \pm 1.0$ & {$[24]$} \\
\hline Body weight at 5 months & ----- & $5.95 \pm 0.14$ & [19] \\
\hline Live weight at 13 weeks & 1045 & $4.70 \pm 1.3$ & {$[22]$} \\
\hline Live weight at 26 weeks & 654 & $6.1 \pm 1.8$ & {$[22]$} \\
\hline Live weight at 39 weeks & 365 & $7.3 \pm 2.2$ & {$[22]$} \\
\hline Live weight at 52 weeks & 219 & $8.4 \pm 2.6$ & {$[22]$} \\
\hline Body weight at 12 months & ---- & $9.49 \pm 0.28$ & [19] \\
\hline $\begin{array}{l}\text { Mature body weight (Kg) } \\
\text { iii. } \quad \text { Morphmetric characteristics }\end{array}$ & --- & 20 to 30 & [6] \\
\hline Height at withers (male, $\mathrm{cm}$ ) & ---- & $46.0 \pm 1.2(\mathrm{SD})$ & {$[10]$} \\
\hline Height at withers (female, $\mathrm{cm}$ ) & ---- & $44.0 \pm 1.5$ (SD) & [10] \\
\hline Body length (cm) & 770 & $53.49 \pm 0.41$ & {$[16]$} \\
\hline Height at withers & 770 & $43.87 \pm 0.39$ & {$[16]$} \\
\hline Abdominal girth & 770 & $65.30 \pm 0.87$ & {$[16]$} \\
\hline
\end{tabular}

${ }^{1}$ Standard deviation.

[23] revealed that almost 50\% of the does had kidding interval ranging between 200 and 250 d while about one-third and one-fifth of the does had parturition intervals of over $250 \mathrm{~d}$ and less than 200 days, respectively. With prolonged kidding intervals, the goal of having three parturitions in two years becomes increasingly difficult to achieve.

Pre-weaning mortality rates (from 1 to 3 months of age) and annual mortality rates were $22.6 \% \pm 15.9 \%$ and $5 \%$, respectively, [23] [24] and could be as high as 50\% [6]. Incidence of high kid mortality reduces doe productivity, as well as the contributions of WAD goat production to sustainable livelihoods. Survival rate of kids was also markedly affected by type of birth, with a higher survival rate associated with kids in single births when 
compared to triplets and quadruplets [20].

Annual doe reproductive index (Kg weaned offspring per doe per year) and doe productivity index (Kg yearlings per doe per year [24]) used to assess the overall performance of WAD goat does under on-station and village conditions are also presented in Table 1 . These indices combine fertility, prolificacy, kid survival to weaning and yearling ages, weight at weaning and yearling ages as well as kidding interval. Means for reproductive index ranged from 5.7 to 9.88 [26] [27]. Doe productivity index ranged from $33.3 \pm 14.3$ to $37.1 \pm 18.1$ [24]. According to [10], WAD goats under restricted environments have not generally outperformed their free ranging counterparts, suggesting that there may still be some management issues that are not well understood or applied.

\subsection{Live Body Weight}

Overall means for live body weight at birth and at different ages up to yearling weight are presented in Table 1 . Mean kid birth weight of $1.28 \pm 0.01 \mathrm{Kg}$ was significantly affected by type of birth (singletons, twins, triplets or quadruplets) and by sex of kid [23]. According to this author, singletons (whether males or females) were consistently heavier at birth than kids in twins, triplets and quadruplets. Similarly, among all litter types, males were heavier than females. These authors noted that the difference between sexes was however, more manifest in singletons. Further, body weight from birth to $9^{\text {th }}$ week of kids derived from different litter types revealed that kids in singletons were heaviest at all ages from birth to $9^{\text {th }}$ week of age, while kids from quadruplets weighed the least [23].

\subsection{Morphometric Characters}

The morphometric traits of adult WAD goats are presented in Table 1. These variables include body length, body depth, height at withers and rump [16]. Linear measurements, like live body weight, showed variations among adult WAD goats, suggesting that this breed of goats is largely unselected. Among the morphological variables, heart girth had the highest correlation $(r=0.88$; $\mathrm{P}<0.001)$ with live body weight (Oseni and Ajayi, 2014, unpublished). These authors also observed that heart girth, whether in linear or multiple regression models accounted for over $77 \%$ of total variability in live weight among WAD goats and showed that the best fit prediction model for live weight of WAD goats included heart girth and one or both of body depth and body length. Similarly, [28] showed that the coefficient of determination of multiple regression models including heart girth and any other linear body measurement on body weight was slightly higher than that of simple regression of heart girth on body weight. Further studies [29] focussed on the comparative multivariate analysis of biometric traits of WAD and Red Sokoto goats. For WAD goats, the study extracted four principal components (PC) with the following loadings: the first PC which had its loadings for chest depth, chest circumference, abdominal circumference, body weight and neck circumference accounted for $66.29 \%$ of total variance. The second PC which was dominated by foreleg length, hindleg length, withers height and rump height covered $9.37 \%$ of total variance. The third PC had its loadings on rump length, rump width, head width, shoulder width and body length accounted for $5.48 \%$ of total variance. The final PC which was only dominated by horn length covered $4.73 \%$ of total variance. The study showed clear spatial racial separation and distinctness in morphology between WAD and Red Sokoto goats.

\section{Genetic Parameters}

Table 2 shows estimates of heritability for some economic traits of WAD goat populations from the literature [30]-[33], with the most recent and comprehensive estimates of genetic parameters by [11]. Literature on estimates of genetic parameters are rather few, indicating that research work on WAD goat breeding and genetics were scarce, suggesting a low level of priority for this area of research. In general, all reproductive traits (including litter size at birth and kidding interval) were low to moderately heritable, as expected for traits related to reproductive and functional traits, on account of the high environmental effects on these traits. Traits that were highly heritable included kid birth weight, sex ratio and sex combination (among twins and triplets) as reported by [32]. These estimates were mostly derived from small sample sizes and/or accompanied by large standard errors, with the exception of [11], which is worthy of note because of the exceptionally large sample sizes and the fact that animals were raised under low trypano-tolerance challenge in low-input production environment. 
Table 2. Heritability estimates for some economic traits in WAD goats from literature.

\begin{tabular}{|c|c|c|}
\hline Trait & Heritability ( \pm SE) & Source \\
\hline Birth weight & $0.50 \pm 0.05$ & [11] \\
\hline Birth weight & $0.59 \pm 0.45$ & [32] \\
\hline Litter size at birth & $0.32 \pm 0.07$ & [33] \\
\hline Litter size at birth & 0.08 to 0.18 (range) & [30] \\
\hline Kidding interval & $0.03 \pm 0.01$ & [33] \\
\hline Weaning weight & $0.14 \pm 0.003$ & [31] \\
\hline Weaning weight & $0.43 \pm 0.07$ & {$[11]$} \\
\hline 3-Month body weight & $0.29 \pm 0.005$ & [31] \\
\hline Pre-weaning growth rate & $0.32 \pm 0.08$ & [11] \\
\hline 6-Month body weight & $0.11 \pm 0.003$ & [31] \\
\hline Post-weaning growth rate & $0.11 \pm 0.05$ & {$[11]$} \\
\hline 9-Month body weight & $0.17 \pm 0.004$ & [31] \\
\hline Yearling weight & $0.30 \pm 0.07$ & {$[11]$} \\
\hline Sex ratio & $0.72 \pm 0.54$ & [32] \\
\hline Sex combination (twins \& triplets) & $0.69 \pm 0.66$ & [32] \\
\hline
\end{tabular}

Genetic correlations [11] [34] among body weights at weaning and at different ages up to yearling weight were positive and significant. In particular, [34] noted that the genetic correlations between weaning weight and three-month body weight $(r=0.65 ; \mathrm{P}<0.01)$ was the highest, and concluded that selection for body weight at early ages (especially at three months) will be beneficial in improving this trait at subsequent ages. Similarly, [11] noted that genetic correlations were mostly moderate to high and suggested that substantial improvement can be made by selection.

On genetic characterization however, it was noted that there are very few reports in the literature that provides detailed information on molecular characterization of WAD goats. [14] determined molecular co-ancestry and the degree of admixture among three goat populations including Djallonké (or WAD goats) in Burkina Faso. Detailed genetic characterization on WAD goats could be done to establish the following: number of alleles, their frequency and diversity, polymorphic information content, as well as expected and observed heterozygosity [35]. [36], using a panel of 21 microsatellite markers, showed that the genetic distance between WAD and Maradi goats was 0.39 , noting that the genetic diversity among their crosses could generate good heterotic advantage and combining abilities. Further, [37] presented data to describe the genetic diversity among the three major Nigerian goat breeds (WAD, Red Sokoto and Sahel goats) at the DQB1 immune gene locus. The study revealed the following: 1) high level of genetic polymorphism among Nigerian goat breeds; 2) the phylogenetic tree from consensus sequences placed Red Sokoto and Sahel goats closer to each other than either was to the WAD goats; 3) sequence polymorphisms among these Nigerian goat breeds may be used in the search for association with disease resistance. On account of its current risk status [2], such comprehensive characterization studies that combine phenotypic, molecular genetic information and field data become imperative.

\section{Conservation of WAD Goats through Utilization}

\subsection{Goals}

The ultimate goals of a communal breeding scheme for WAD goats are to: 1) improve the risk status of WAD goats through conservation measures that are hinged on sustainable utilization; and 2) provide backyard WAD goat farmers with improved germ-plasm, through the supply of superior WAD goat bucks for mating. 


\subsection{Considerations}

Critical considerations in the design of conservation measures for WAD goats under backyard systems include the following: 1) taking cognizance of the needs, priorities and perceptions of flock owners in the design and formulation of breeding programmes and strategies [38]; 2) ensure that breeding programmes are compatible with the needs of goat farmers and their production system; 3) that the ensuing breeding programmes are relatively simple in design and involve low risks [39]; 4) accommodate the role of local knowledge systems in the maintenance of a diverse genetic pool of WAD goats, in particular, and animal care and management in general [40].

Thus, from the foregoing, the definition of breeding objectives will be done by the WAD goat farmers. Such breeding objectives should take into consideration, the multi-functional roles of WAD goats in the traditional setting in West and Central Africa, including the following: source of meat, ceremonies, savings (e.g. bankon-hooves), settlement of dowries/bride prizes and other traditional roles (e.g. sacrifice and divination), where WAD goats with specific coat colours are required. According to [41], breeding policies need to incorporate such multi-functional roles in the design of breeding programmes in order to guarantee their success. [42] outlined detailed community-based organization of genetic improvement of livestock production while [43] presented results of a participatory process of the ranking of traits of WAD goats by farmers in Benin Republic. Such participatory and community-based approaches to the design of livestock improvement schemes represent a critical step in the definition of breeding objectives and contribute to the development of sustainable communal breeding schemes.

\subsection{Challenges}

Major challenges in the implementation of a communal breeding scheme for WAD goat owners include: 1) among stock owners, the practice of selling off the fastest growing males for slaughter, leaving the slow-growing type in the flocks, thereby creating negative selection and reducing the quality of their flocks [44] [45]; 2) small flock sizes of backyard WAD goat units [6]; 3) the involvement and mobilization of farmers in the design and implementation of communal breeding schemes in terms of project ownership and as final beneficiaries [38] [46]; 4) establishing and sustaining an on-farm recording system, a pre-requisite for any successful breeding programme [41]. Solutions to these challenges will lead to the design and implementation of sound communal breeding schemes for WAD goats under backyard systems.

\subsection{Communal Breeding Schemes}

A proposed breeding scheme for WAD goats under backyard systems can be operated on a communal or cooperative basis, and could involve the implementation of a dispersed open nucleus breeding programme described in [47]. The choice of a communal scheme is due to the fact that the pre-dominant backyard WAD goat units found all across west and central Africa are devoid of sophisticated breeding centres involving progeny testing or artificial insemination. Thus, a cooperative breeding scheme that is relatively simple in design and implementation [39], owned and managed by the farmers becomes a viable option. The ensuing breeding scheme will contribute to the maintenance and provision of WAD goat germ-plasm for use by farmers, especially by supplying superior bucks for natural mating in village flocks. The use of dispersed open nucleus systems [47] is particularly advantageous because it will promote animal (buck) exchange between communities, thereby help to stem the tide of inbreeding within villages, and facilitate conservation and diversity in the gene pool of WAD goats. Key steps in the actualization of the breeding plan are hinged on the following: 1) Farmer mobilization in each locality or region; 2) formation of a WAD goat cooperative breeding scheme, ultimately to be owned, run and managed by the farmers on a cooperative basis; 3) animal identification and on-farm recording. The implementation of the breeding scheme could be based on the open nucleus breeding scheme that maintains males only, as reported by [48] and [49] for Djallonké sheep in Cote d’Ivoire. For simplicity and ease of implementation, the screening of young bucks of WAD goats could involve two phases-1) an on-farm pre-selection phase, based on live weight at $90 \mathrm{~d}$; and 2) an on-station final selection phase based on yearling weight, followed by the distribution of the selected bucks to participating farmers. Critical to the success of this communal breeding scheme is the dissemination and efficient use of superior bucks from the nucleus units, among all registered and participating farmers, through some traditional pre-agreed stock sharing formula to be designed and implemented by them. 


\section{Conclusion}

The paper draws attention to current information on the risk status and characteristics of WAD goats under backyard systems in west and central Africa. Details were provided on trait-level information relating to qualitative, reproductive, growth and morphological characters. Few estimates of genetic parameters and molecular characterization in the literature indicate the low priority accorded breeding and genetics in WAD goat research. Critical steps in the design of a communal genetic improvement scheme for WAD goats based on a dispersed open nucleus breeding scheme were discussed. The ultimate goal is to provide WAD goat germplasm through the supply of superior WAD bucks to participating farmers in backyard systems in villages.

\section{Acknowledgements}

1) University Research Committee, Obafemi Awolowo University, Ile-Ife, Nigeria for a research grant code: 11812 AWQ; 2) WAD Goat Project (1982 to 1993) conducted at the Obafemi Awolowo University, Ile-Ife, Nigeria, with financial support from the government of the Netherlands; 3) The dedicated owners of backyard WAD goat production system, who constitute our clientele group.

\section{References}

[1] Gall, C. (1996) Goat Breeds of the World. CTA-Margraf Verlag, Germany, 186 p.

[2] DAGRIS (2008) Domestic Animal Genetic Resources Information System (DAGRIS). General Breed Information for Djallonke Goats. http://dagris.ilri.org/dagris/location.asp?ID=803

[3] Epstein, H. (1971) The Origin of the Domestic Animals of Africa. Africana Publication Corporation, New York, 214220.

[4] Leak, S., Faye, D. and Geerts, S. (2002) Genetic Resistance to Vectors and Vector-Borne Diseases in Indigenous West African Livestock. CPTV Newsletter, 6, 36-38.

[5] Central Intelligence Agency (CIA) (2008) World Fact Book. Country Report on Nigeria and Other Countries in West and Central Africa. https://www.cia.gov/library/publications/the-world-factbook/geos/ni.html

[6] Ademosun, A.A. (1993) The Scope for Improved Small Ruminant Production in the Humid Zone of West and Central Africa: The Approach of the West African Dwarf Goat Project. In: Ayeni, A.O. and Bosman, H.G., Eds., Goat Production Systems in the Humid Tropics, Pudoc Scientific Publishers, Wageningen, 2-13.

[7] Devendra, C. and Mcleroy, G.B. (1982) Goat and Sheep Production in the Tropics. Intermediate Tropical Agricultural Series, Longman Scientific and Technical Publishers, Longman, London, 218-219.

[8] Rege, J.E.O. (1994) Indigenous African Small Ruminant Resources: A Case for Characterization and Improvement. In: Lebbie, S.H.B., Rey, B. and Irungu, E.K., Eds., Small Research \& Development in Africa. Proceedings of the 2nd Biennial Congress of the African Small Ruminant Research Network, Arusha, 7-11 December 1992, 205-212.

[9] Blench, R. (1999) Traditional Livestock Breeds: Geographical Distribution and Dynamics in Relation to the Ecology of West Africa. Working Paper 122, Overseas Development Institute (ODI), London.

[10] Ngere, L.O., Adu, I.F. and Okubanjo, I.O. (1984) The Indigenous Goats of Nigeria. Animal Genetic Resources Information, 3, 1-9.

[11] Bosso, N.A., Cissé, M.F., van der Waaij, E.H., Falla, A. and van Arendonk, J.A.M. (2007) Genetic and Phenotypic Parameters of Body Weight in West African Dwarf Goat and Djallonké Sheep. Small Ruminant Research, 67, 271-278. http://dx.doi.org/10.1016/j.smallrumres.2005.11.001

[12] Goosen, B. (1998) Sustainability of Small Ruminant Production in the Gambia with Special Reference to the Improved Husbandry of Trypanotolerant Sheep. Veterinary Parasitology, 79, 283-297.

[13] Hoeven, E., Leak, S., Hanotte, O., Jianlin, H. and Fidalis, M.N. (2004) Diversity and Mixture in West African Goats. ITC Newsletter, January-June 2004, 5-17.

[14] Traoré, A., Álvarez, I., Tambourá, H.H., Fernández, I., Kaboré, A., Royo, L.J., Gutiérrez, J.P., Sangaré, M., OuédraogoSanou, G., Toguyeni, A., Sawadogo, L. and Goyache, F. (2008) Genetic Characterisation of Burkina Faso Goats Using Microsatellite Polymorphism. Livestock Science, 123, 322-328.

[15] Odubote, I.K. (1992) Characterization of the WAD Goat for Certain Qualitative Traits. Nigerian Journal of Animal Production, 19, 37-41.

[16] Ozoje, M.O. and Mgbere, O.O. (2002) Coat Pigmentation Effects in West African Dwarf Goats: Live Weights and Body Dimensions. Nigerian Journal of Animal Production, 29, 5-10.

[17] Odubote, I.K. (1994) Influence of Qualitative Traits on the Performance of West African Dwarf Goats. Nigerian Jour- 
nal of Animal Production, 21, 25-28.

[18] Jewell, P.A. (1998) Behavioural and Other Aspects of the Adaptations of Rare Breeds to Their Surroundings. In: Lewis, R.M., Alderson, G.L.H. and Mercer, J.T., Eds., The Potential Role of Rare Livestock Breeds in UK Farming Systems, British Society of Animal Science Meeting and Workshop Publication, 21-27.

[19] Sumberg, J.E. and Mach, S.D. (1985) Village Production of WAD Goats and Sheep in Nigeria. Tropical Animal Health and Production, 17, 135-140. http://dx.doi.org/10.1007/BF02355872

[20] Odubote, I.K., Akinokun, J.O. and Ademosun, A.A. (1993) Production Characteristics of West African Dwarf Goats under Improved Management Systems in the Tropics. In: Ayeni, A.O. and Bosman, H., Eds., Goat Production Systems in the Humid Tropics, Proceedings of an International Workshop, Pudoc Scientific Publishers, Wageningen, 202-207.

[21] Broek van den, A. (1993) Goat Production in the Mono-Department (Republic of Benin): From Survey Methodology to Research Proposals. In: Ayeni, A.O. and Bosman, H., Eds., Goat Production Systems in the Humid Tropics, Proceedings of an International Workshop, Pudoc Scientific Publishers, Wageningen, 154-159.

[22] Bosman, H.G. and Ayeni, A.O. (1993) Zootechnical Assessment of Innovations as Adapted and Adopted by the Goat Keepers. In: Ayeni, A.O. and Bosman, H.G., Eds., Goat Production Systems in the Humid Tropics, Pudoc Scientific Publishers, Wageningen, 45-57.

[23] Egbunike, G.N., Akusu, M.O. and Carew, B.A.R. (1993) Vital Reproductive Statistics of West African Dwarf Does. In: Ayeni, A.O. and Bosman, H.G., Eds., Goat Production Systems in the Humid Tropics, Pudoc Scientific Publishers, Wageningen, 208-212.

[24] Bosman, H.G. (1995) Productivity Assessments in Small Ruminant Improvement Programmes. A Case Study of the West African Dwarf Goat. Thesis, Grafisch Bedrijf Pons \& Looijen b.v. Wageningen, Wageningen, 224 p.

[25] Chiboka, O., Somade, B. and Montsma, G. (1988) Reproduction of WAD Goats-A Summary of Research at Ile-Ife, Nigeria. In: Smith, O.B. and Bosman, H.G., Eds., Goat Production in the Humid Tropics, Proceedings of a Workshop at the University of Ife, Ile-Ife, 20-24 July 1987, 125-136.

[26] Reynolds, L. and Adeoye, S.A.O. (1986) Planted Leguminous Plants and Livestock Production. The International Workshop on Alley Farming for Humid and Sub-Humid Regions of Tropical Africa, International Institute for Tropical Agriculture (IITA), Ibadan, 13.

[27] Adu, I.F., Adeniyi, A.O. and Taiwo, B.B.A. (1988) Production Characteristics of a Herd of West African Dwarf Goats at Ubiaja, Bendel State of Nigeria. In: Smith, O.B. and Bosman, H.G., Eds., Goat Production in the Humid Tropics, Proceedings of a Workshop at the University of Ife, Ile-Ife, 20-24 July 1987, 140-144.

[28] Lawrence, T.L. and Fowler, V.R. (1997) Growth of Farm Animals. CAB International, Wallingford, 330. Cited by Atta, M. and El Khidr, O.A. (2004) Use of Heart Girth, Wither Height and Scapulo-Ischial Length or the Prediction of Live Weight of Nilotic Sheep. Small Ruminant Research, 55, 233-237.

[29] Yakubu, A., Salako, A.E. and Imumorin, I.G. (2011) Comparative Multivariate Analysis of Biometric Traits of WAD and Red Sokoto Goats. Tropical Animal Health and Production, 43, 561-566. http://dx.doi.org/10.1007/s11250-010-9731-y

[30] Wilson, R.T., Muraiyi, T. and Rocha, A. (1989) Indigenous African Small Ruminant Strains with Potentially High Reproductive Performance. Small Ruminant Research, 2, 107-117. http://dx.doi.org/10.1016/0921-4488(89)90036-9

[31] Odubote, I.K. and Akinokun, J.O. (1992) Estimates of Genetic Parameters for Economic Traits in West African Dwarf Goats. Nigerian Journal of Animal Production, 19, 114-119.

[32] Adebambo, O.A., Samuel, A.O. and Onakade, A.D. (1994) Causes of Variation in Reproductive Performance of West African Dwarf Goat. Nigerian Journal of Animal Production, 21, 29-36.

[33] Odubote, I.K. (1996) Genetic Analysis of the Reproductive Performance of West African Dwarf Goats in the Humid Tropics. In: Lebbie, S.H.B. and Kagwini, E., Eds., Small Ruminant Research \& Development in Africa, Proceedings of the 3rd Biennial Congress of the African Small Ruminant Research Network, Kampala, 5-9 December 1994, 33-36.

[34] Odubote, I.K. and Akinokun, J.O. (1994) Estimates of Phenotypic and Genetic Correlations in West African Dwarf Goats. Nigerian Journal of Animal Production, 21, 47-50.

[35] Thilagam, K., Ramamoorthi, J., Sivaselvam, S.N., Karthickeyan, S.M.K. and Thangaraju, P. (2006) Kanniadu Goats of Tamilnadu, India: Genetic Characterization through Microsatellite Markers. Livestock Research for Rural Development, 18. http://www.cipav.org.co/lrrd/lrrd18/10/thill18149.htm

[36] Adebambo, A.O., Williams, J.L., Blott, S. and Urquart, B. (2011) Genetic Distance between Two Popular Nigerian Goat Breeds Used for Milk Production. Livestock Research for Rural Development, 23. http://www.lrrd.org/lrrd23/2/adeb23.26.htm

[37] Yakubu, A., Salako, A.E., De Donato, M., Takeet, I., Peters, S.O., Adefenwa, M.A., Okpeku, M., Wheto, M., Agaviezor, B.O., Sanni, T.M., Ajayi, O.O., Onasanya, G.O., Ekundayo, O.J., Ilori, B.M., Amusan, S.A. and Imumorin, I.G. 
(2013) Genetic Diversity in Exon 2 of the Major Histocompatibility Complex Class II DQB1 Locus in Nigerian Goats. Biochemical Genetics, 51, 954-966. http://dx.doi.org/10.1007/s10528-013-9620-y

[38] Zarate, A.V. (1996) Breeding Strategies for Marginal Regions in the Tropics and Sub-Tropics. Animal Research \& Development, 43-44, 100-118.

[39] Kosgey, I.S. (2004) Breeding Objectives and Breeding Strategies for Small Ruminants in the Tropics. Ph.D. Thesis, Animal Breeding \& Genetics Group, Wageningen University, Wageningen, 272 p.

[40] Oseni, S.O., Ajayi, B.A. and Muritala, I. (2006) Mainstreaming Farmer Innovativeness in WAD Goat Genetic Improvement Schemes in the Development of Sustainable Goat Production Systems in South-Western Nigeria. In: $A b-$ stracts of Proceedings, Innovation Africa Symposium, Kampala, 20-23 November 2006, 75.

[41] Musa, M.A., Peters, K.J. and Ahmed, M.K.A. (2006) On-Farm Charcaterization of Butana and Kenana Cattle Breeds and Production Systems in Sudan. Livestock Research for Rural Development, 18. http://www.lrrd.org/lrrd18/12/musa18177.htm

[42] Kahi, A.K., Rewe, T.O. and Kosgey, I.S. (2005) Sustainable Community Based Organizations for the Genetic Improvement of Livestock in Developing Countries. Outlook on Agriculture, 34, 261-270. http://dx.doi.org/10.5367/000000005775454706

[43] Dossa, L.H., Wollny, C. and Gauly, M. (2007) Spatial Variation in Goat Populations from Benin as Revealed by Multivariate Analysis of Morphological Traits. Small Ruminant Research, 73, 150-159. http://dx.doi.org/10.1016/j.smallrumres.2007.01.003

[44] Reynolds, L. and Adediran, S. (1993) Composition of Village Goat Production Herds in Southwest Nigeria. Small Ruminant Research, 13, 49-53. http://dx.doi.org/10.1016/0921-4488(94)90030-2

[45] Terrisse, B.F. (2005) Improving the Performance of Indigenous Sheep Breeds. Leisa Magazine, September 2005, 16-17.

[46] Oseni, S.O., Sonaiya, E.B., Omitogun, O.G., Ajayi, B.A. and Muritala, I. (2006) West African Dwarf Goat Production under Village Condition: 1. Characterization and the Establishment of Breed Standards. Proceedings of Conference on International Agricultural Research for Development, Book of Abstracts, Tropentag 2006, University of Bonn, Bonn, 11-13 October 2006, 526.

[47] Tibbo, M. (2008) Animal Breeding in Developing Countries Context. NCCR Trade Regulation IP-9 Workshop on Animal Breeding, Innovation, Trade \& Proprietary Rights, Berne, 27-28 November 2008, 45 p.

[48] Yapi-Gnoare, C.V. (2000) The Open Nucleus Breeding Programme of the Djalloke sheep in Cote d'Ivoire. In: Galal, S., Boyazoglu, J. and Hammond, K., Eds., Workshop on Developing Breeding Strategies for Lower Input Animal Production Environments, ICAR Series 3, Bella, 22-25 September 1999, 283-292.

[49] Yapi-Gnaore, C.V., Dagnogo, B. and Oya, B.A. (2003) Community-Based Livestock Improvement and Conservation: Experience from Open-Nucleus Breeding Programmes in West Africa. FAO, Rome, 89-95.

http://www.fao.org/docrep/006/Y3970E/y3970e09.htm 
Scientific Research Publishing (SCIRP) is one of the largest Open Access journal publishers. It is currently publishing more than 200 open access, online, peer-reviewed journals covering a wide range of academic disciplines. SCIRP serves the worldwide academic communities and contributes to the progress and application of science with its publication.

Other selected journals from SCIRP are listed as below. Submit your manuscript to us via either submit@scirp.org or Online Submission Portal.
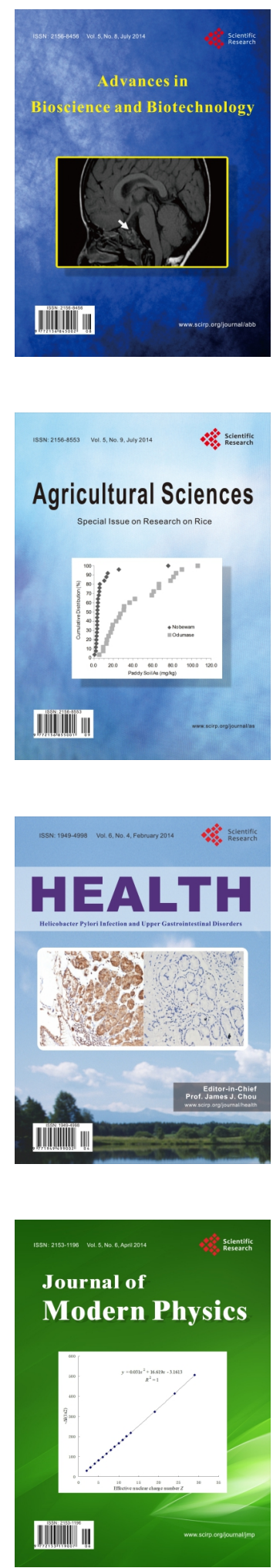
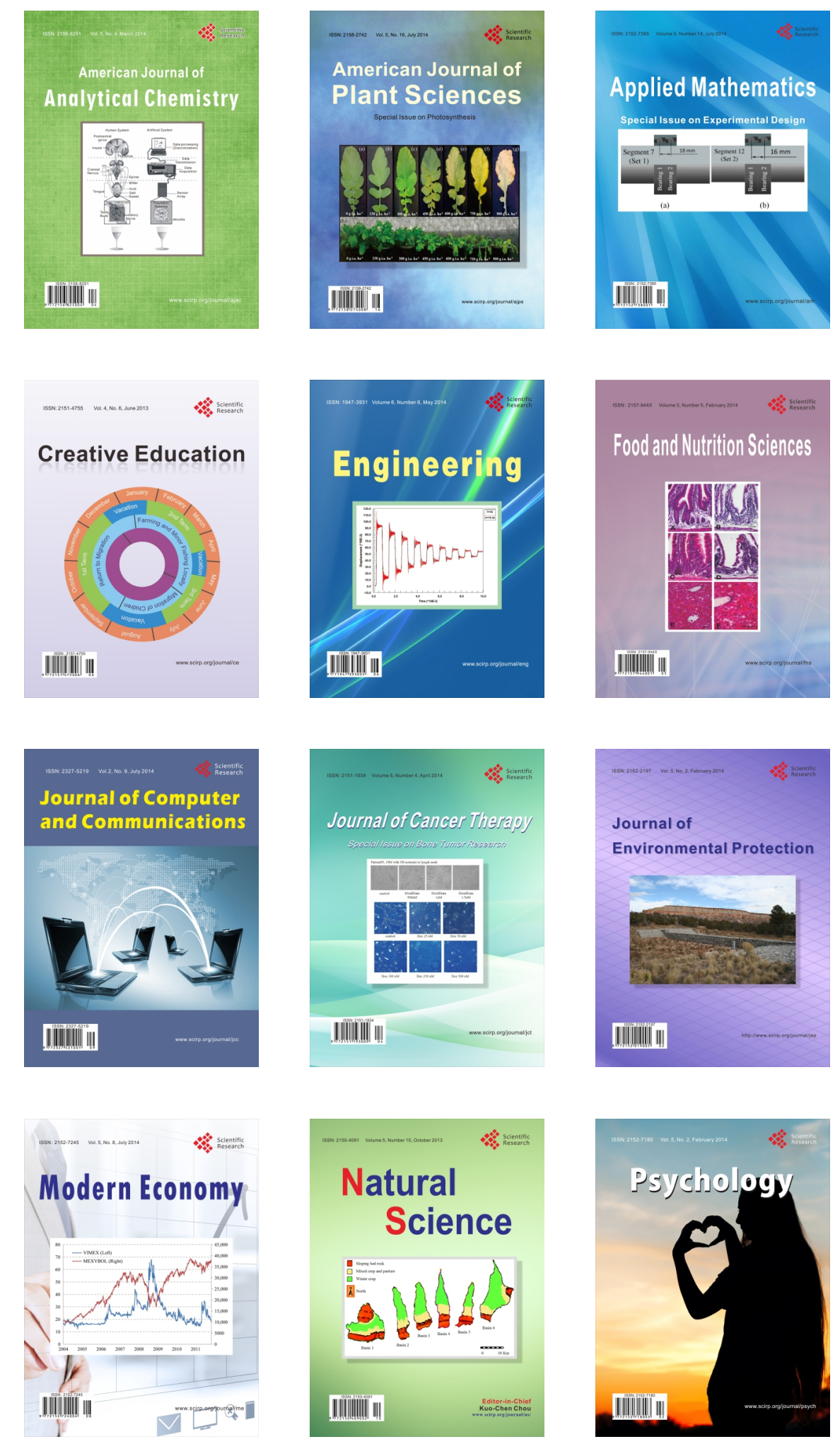